\title{
Pencirian Geomekanik Jasad Batuan dan Analisis Kestabilan Cerun di Laman Granview, Saujana Puchong, Selangor, Malaysia
}

(Geomechanical Characterisation of Rock Mass and Slope Stability Analysis at Laman Granview, Saujana Puchong, Selangor, Malaysia)

\author{
ABDUl GHANI RAFEK, ONG BOK CHENG \& GOH THIAN LAI*
}

\begin{abstract}
ABSTRAK
Satu kajian pencirian geomekanik jasad batuan dan analisis kestabilan dua cerun terletak di tapak pembinaan Laman Granview di Saujana Puchong, Selangor telah dijalankan. Kawasan kajian merupakan sebahagian Formasi Bukit Kenny. Kajian telah dijalankan pada dua buah cerun potongan di tapak binaan adalah survei ketakselanjaran dan pencirian mekanik batuan. Kuarzit adalah litologi yang dominan di kawasan ini dengan sedikit filit. Ujian mekanik batuan berikut dijalankan: Ujian kekuatan mampatan sepaksi, ujian indeks beban titik dan ujian kekuatan regangan Brazil, ujian pantulan tukul Schmidt dan ujian Skleroskop Shore. Ujian kemiringan untuk penentuan kekasaran permukaan satah ketakselanjaran dijalankan pada sampel bongkah batuan. Hasil survei ketakselanjaran menunjukkan terdapat empat set ketakselanjaran yang utama di cerun L1 dengan nilai arah kemiringan/sudut kemiringan $62^{\circ} / 42^{\circ}, 261^{\circ} / 79^{\circ}$, $281^{\circ} / 59^{\circ}$ dan $237^{\circ} / 71^{\circ}$. Di cerun L2, terdapat tiga set ketakselanjaran utama iaitu dengan nilai arah kemiringan/sudut kemiringan $81 \% 41^{\circ}, 171^{\circ} / 71^{\circ}$ dan $198 \% 60^{\circ}$. Untuk ujian kemiringan, nilai purata sudut geseran puncak $\left(f_{p}\right)$ permukaan satah ketakselanjaran batu kuarzit dengan Pekali Kekasaran Kekar (PKK) 8-10 adalah 61 ${ }^{\circ}$. Ketakselanjaran batuan kuarzit dengan nilai PKK 10-12 pula mempunyai purata sudut geseran puncak $\left(f_{p}\right)$ sebanyak $73^{\circ}$. Manakala, nilai purata sudut geseran puncak $\left(f_{p}\right)$ batuan filit dengan PKK 4-6 ialah 56 . Berdasarkan analisis kinematik, cerun L1 adalah stabil. Ragam kegagalan cerun L2 pula adalah kegagalan satah tetapi nilai sudut geseran permukaan satah yang tinggi akan menghalang kegagalan berlaku. Nilai perkadaran jasad batuan (RMR) bagi batuan kuarzit ialah 77 dan batuan filit ialah 66 dengan kedua-dua tergolong dalam batuan yang baik dalam kelas II.
\end{abstract}

Kata kunci: Analisis kinematik kestabilan cerun; perkadaran jasad batuan (RMR); ujian kemiringan

\section{ABSTRACT}

A study was conducted at the construction site of Laman Granview, Saujana Puchong, Selangor to study the stability of two slopes and the geomechanical properties of the rock mass. The study site is part of the Kenny Hill Formation. Surveys were carried out at two cut slopes at construction site were discontinuity surveys and rock mechanics characterisation. Quartzite is the dominant lithology in this area with minor amounts of phyllite. The following rock mechanics tests were conducted: Uniaxial compressive test, point load index test, Brazilian tensile strength test, Schmidt rebound hammer test and Shore Scleroscope test. Tilt tests for determining the surface roughness of discontinuities were conducted on rock block. The results of discontinuities survey showed that there are four major sets of discontinuities at cut slope L1 with dip directions/dip values of $62^{\circ} / 42^{\circ}, 261^{\circ} / 79^{\circ}, 281^{\circ} / 59^{\circ}$ and $237^{\circ} / 71^{\circ}$. At cut slope L2, there are three major discontinuities sets with dip direction/dip values of $81^{\circ} / 41^{\circ}, 171^{\circ} / 71^{\circ}$ and $198^{\circ} / 60^{\circ}$. For the tilt test results, the average peak friction angle $\left(f_{p}\right)$ of the discontinuity surface for quartzite with Joint Roughness Coefficient (JRC) 8-10 is 61 . Discontinuity planes of quartzite with JRC of 10-12 have an average peak friction angel $\left(f_{p}\right)$ value of $73^{\circ}$, while phyllite with JRC 4-6 has an average peak friction angle $\left(f_{p}\right)$ value of $56^{\circ}$. Based on kinematic slope stability analysis, cut slope L1 is stable. Potential failure for cut slope L2 is plane failure but the high friction angle of the discontinuity surface will prevent failure. The Rock Mass Rating (RMR) obtained for quartzite is 77 and phyllite is 66 which both of which are classify as good rock mass in class II.

Keywords: Kinematic slope stability analysis; rock mass rating (RMR); tilt test

\section{PENGENALAN}

Parameter mekanik bahan dan jasad batuan memainkan peranan penting dalam kejuruteraan batuan. Pencirian ketakselanjaran bersama dengan orientasinya pula menentukan kestabilan sesebuah cerun batuan. Kaedah makmal dan lapangan boleh mencirikan jasad batuan bersama dengan ketakselanjaran manakala kestabilan cerun batuan dapat ditentukan dengan menggunakan analisis kinematik kestabilan cerun. Sebelum ini, pengelasan geomekanik dan pencirian kekasaran permukaan ketakselanjaran jarang diambil kira dalam analisis kestabilan cerun. Kajian kepustakaan mendapati 
bahawa pencirian geomekanik dan kekasaran permukaan ketakselanjaran mula mendapat perhatian penyelidik tempatan. Abdul Ghani and Goh $(2015,2012)$, Ailie et al. (2017, 2016) dan Goh et al. (2014a) menghasilkan hubungan empirik antara sudut geseran puncak batuan syis dan granit dengan pekali kekasaran kekar (PKK) untuk mencirikan kekasaran permukaan ketakselanjaran. Goh et al. (2012) mengambil kira impak proses luluhawa terhadap kekuatan geomekanik bahan batuan granit dan syis. Norbert et al. (2016) menganalisis kestabilan cerun dengan menggunakan sistem pengelasan Indeks Kekuatan Geologi. Manakala Goh et al. (2016a, 2015a, 2015b, 2014b) mengkaji kekuatan mampatan sepaksi batuan dengan mengunakan ujian ultrasonik. Goh et al. (2016b, 2016c) menilai kestabilan cerun dengan menggunakan kriteria Hoek dan Brown dan sistem pengelasan perkadaran jasad cerun. Oleh itu, tujuan utama kajian ini ialah pencirian ketakselanjaran berdasarkan cadangan International Society for Rock Mechanics (ISRM), pengelasan geomekanik jasad batuan berdasarkan sistem perkadaran jasad batuan (RMR) (Bieniawski 1979) serta analisis kestabilan cerun.

Kawasan kajian (Rajah 1) terletak di Saujana Puchong, Selangor bersebelahan dengan Taman Orang Asli Saujana Puchong dan Taman Saujana Puchong. Kawasan kajian bertempat di dua cerun bukit yang terletak di kawasan pembinaan kediaman mewah Laman Granview dengan kedua-dua muka cerun (Rajah 2) mempunyai orientasi yang berbeza.

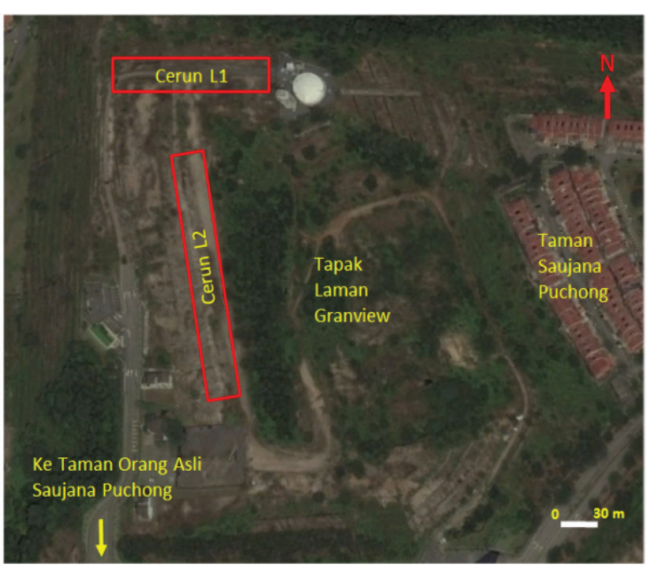

RAJAH 2. Kedudukan cerun L1 dan L2 di Laman Granview, Saujana Puchong, Selangor Darul Ehsan

Sumber: Google Map (2017)

\section{BAHAN DAN KAEDAH}

\section{GEOLOGI KAWASAN KAJIAN}

Kawasan kajian terletak dalam Formasi Bukit Kenny yang merupakan suatu jujukan batuan metasedimen klastik yang terdiri daripada selang lapis unit arenit dan unit argilit yang menindih Batu Kapur Kuala Lumpur (Stauffer 1973). Jenis batuan yang terdapat di dalam Formasi Bukit Kenny termasuk kuarzit, sabak, syis, filit, syis bergrafit dan rijang. Jujukan Formasi Bukit Kenny direjah oleh granit

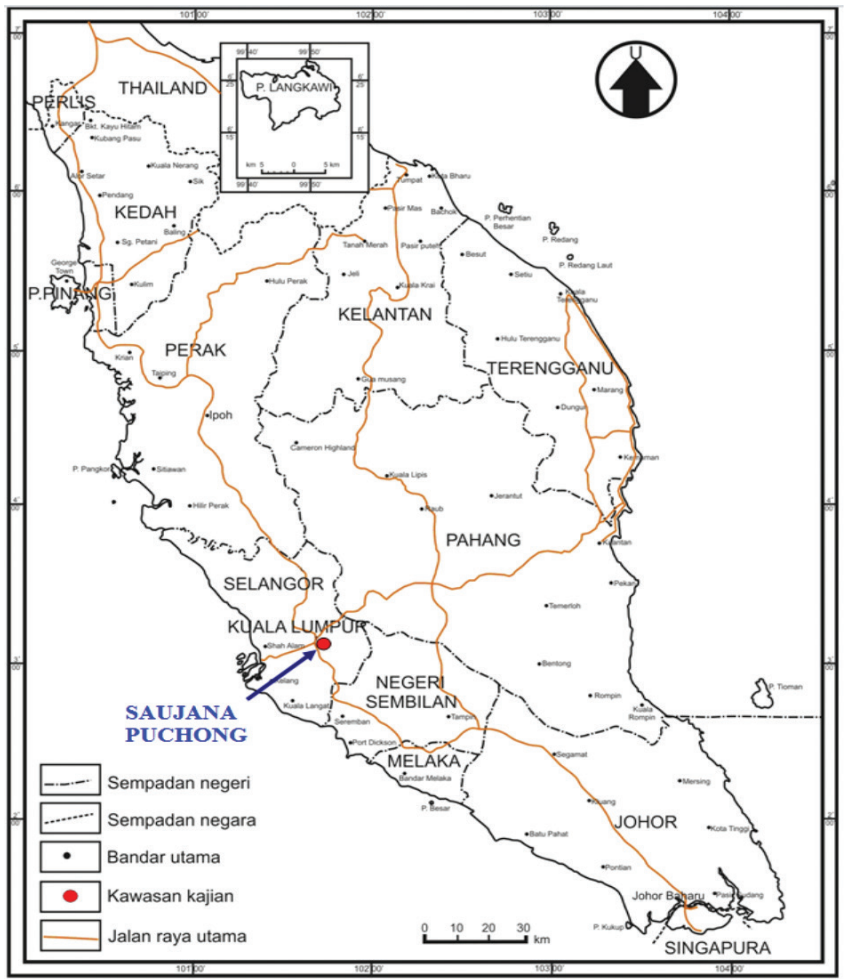

RAJAH 1. Peta lokasi kajian di Laman Granview di Saujana Puchong, Selangor Darul Ehsan 
berusia Trias. Mereka juga menganggarkan ketebalan Formasi Kenny Hill sekitar 1200-1500 meter berdasarkan keadaan sinklin itu. Abdullah Sani (1985) yang membuat kajian tentang formasi ini di Salak Tinggi menjumpai ammonoid dan batang krinoid yang dianggarkan berusia Perm. Beliau juga menyatakan Formasi Kenny Hill terbentuk di sekitaran pengenapan laut cetek. Seterusnya ditambah beliau bahawa Formasi Kenny Hill menindan Syis Hawthornden secara tidak selaras.

\section{SURVEI KETAKSELANJARAN}

Kaedah yang digunakan untuk survei ketakselanjaran ialah kaedah garis imbasan seperti yang dibincangkan dengan mendalam oleh Ibrahim Komoo dan Ibrahim Abdullah (1983) serta Ibrahim Komoo et al. (1985). Garis imbasan ialah satu garis lurus bayangan yang ditarik mendatar pada permukaan singkapan dengan semua set ketakselanjaran yang dipintasinya dirakamkan. Singkapan batuan yang sesuai dipilih untuk dijalankan survei ketakselanjaran dan merupakan singkapan batuan yang boleh mewakili keseluruhan ketakselanjaran di kawasan itu. Dua lokaliti telah dipilih iaitu L1 dan L2 dengan singkapan batuan di kedua-dua lokaliti ini mempunyai orientasi muka cerun yang berbeza. Survei ketakselanjaran kemudian dijalankan pada kedua-dua lokaliti ini untuk mendapatkan data yang mencukupi untuk dianalisis.

\section{UJIAN GEOMEKANIK}

Bongkah pelbagai saiz dikutip dan dibawa balik untuk ujian makmal. Kebanyakan ujian yang dilakukan menggunakan sampel dalam bentuk teras berdiameter $54 \mathrm{~mm}$. Sampel batuan yang bersaiz besar digerudi dengan mesin gerudi, SHIBUYA. Teras batuan yang telah digerudi kemudian dipotong kepada saiz yang dikehendaki. Antara ujian yang dilakukan adalah ujian kekuatan batuan seperti ujian kekuatan mampatan sepaksi, ujian kekuatan beban titik dan ujian kekuatan regangan Brazil. Ujian kekerasan yang dijalankan ialah ujian pantulan tukul Schmidtdan ujian kekerasan Skleroskop Shore (Brown 1981).

\section{UJIAN KEMIRINGAN}

Ujian kemiringan dijalankan di makmal pada sepasang blok batuan dengan satah ketakselanjaran semula jadi untuk menentukan sudut geseran permukaan sebenar satah tersebut. Sudut geseran ialah sudut sesuatu batuan itu gagal dan menggelongsor sekiranya melebihi nilai sudut tersebut. Satah lemah atau satah gelongsoran sampel diuji dengan profiler untuk mendapatkan nilai Pekali Kekasaran Kekar, (JRC) (Jadual 1) diikuti dengan ujian kemiringan untuk mendapatkan sudut seperti yang ditunjukkan pada Rajah 3.

\section{PERKADARAN JASAD BATUAN}

Skema pengelasan yang dicadangkan oleh Bieniawski (1979) iaitu Perkadaran Jasad Batuan (RMR) digunakan
JADUAL 1. Darjah penggelombangan permukaan satah ketakselanjaran yang diperoleh daripada profiler dengan Nilai Pekali Kekasaran Kekar (JRC)

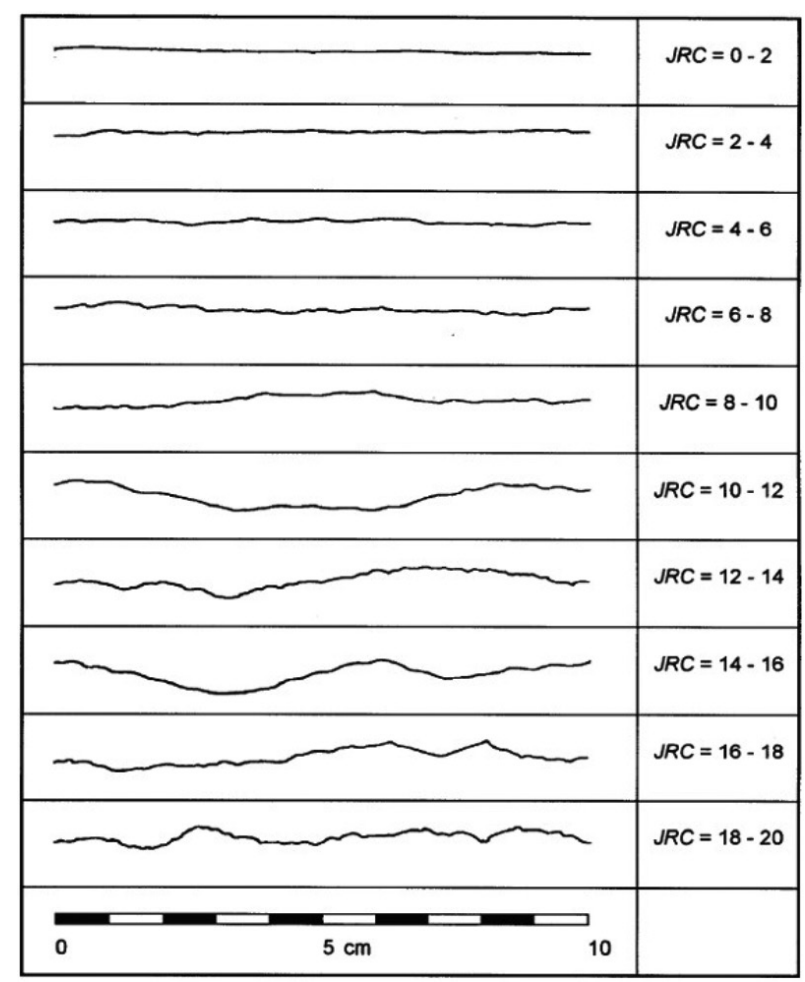

Sumber: Brown (1981)

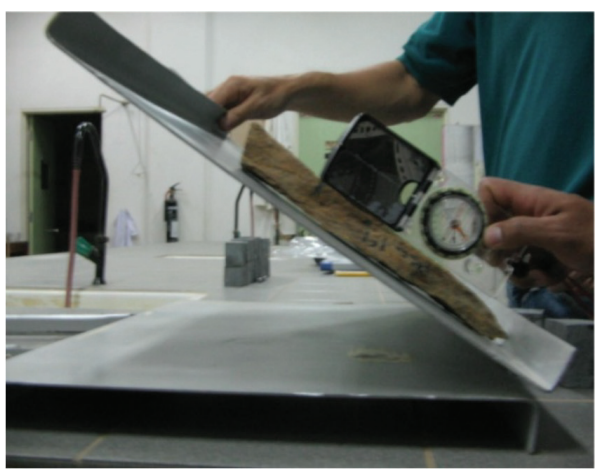

RAJAH 3. Peralatan untuk ujian kemiringan. Ujian kemiringan dijalankan untuk menentukan sudut geseran puncak $\left(\mathrm{f}_{\mathrm{p}}\right)$ kekasaran permukaaan ketakselanjaran

untuk pengelasan jasad batuan. Terdapat lima parameter utama yang ditekankan dalam skema pengelasan Bieniawski (1979), iaitu kekuatan batuan utuh, penanda mutu batuan (Deere 1963), jarak antara ketakselanjaran, keadaan ketakselanjaran dan keadaan air tanah. Kelimalima parameter ini dikenali sebagai parameter asas. Kesemua parameter ini dinyatakan dalam nilai perkadaran tertentu dan dijumlahkan untuk mendapatkan nilai perkadaran jasad batuan asas $\left(\mathrm{RMR}_{\text {asas }}\right)$. 


\section{ANALISIS KINEMATIK CERUN}

Kaedah yang digunakan dalam analisis kestabilan cerun ialah kaedah ujian Markland (Hoek \& Bray 1981). Keupayaan kegagalan diramalkan dengan mempertimbangkan sudut geseran permukaan satah ketakselanjaran puncak, $f_{p}$ yang diperoleh daripada ujian kemiringan. Satah muka cerun, satah ketakselanjaran dan sudut geseran puncak $\left(f_{p}\right)$ diplotkan pada stereograf. Sesuatu cerun berpotensi gagal sekiranya sudut kemiringan muka cerun $\left(\Psi_{\mathrm{f}}\right)$ melebihi sudut tunjaman persilangan dua satah ketakselanjaran atau sudut kemiringan sesuatu satah ketakselanjaran $\left(\Psi_{\mathrm{i}}\right)$ dan keduadua sudut ini melebihi sudut gesaran puncak, $f_{p}$.

\section{HASIL DAN PERBINCANGAN}

Hasil ujian geomekanik batuan menunjukkan jasad batuan di kawasan kajian adalah kuat. Nilai kekuatan mampatan sepaksi batuan kuarzit adalah berjulat sekitar $75 \mathrm{MPa}$ hingga $207 \mathrm{MPa}$ dengan nilai purata 131.1 MPa (Jadual 2). Nilai kekuatan mampatan sepaksi batuan filit adalah 5.76 MPa. Ujian beban titik bagi sampel teras kuarzit menunjukkan nilai indeks berjulat antara 1.77-10.06 MPa dengan nilai purata $8.14 \mathrm{MPa}$. Ujian beban titik untuk sampel ketulan kuarzit berjulat 0.63-3.44 MPa dengan nilai purata $1.89 \mathrm{MPa}$. Ujian beban titik untuk sampel ketulan filit berjulat 0.09-0.60 MPa dengan nilai purata $0.25 \mathrm{MPa}$. Bagi ujian kekuatan regangan Brazil sampel cakera kuarzit, nilai kekuatan regangan yang diperoleh berjulat 6.27-19.34 $\mathrm{MPa}$ dengan nilai purata $7.51 \mathrm{MPa}$.
Batuan kuarzit yang terdapat di kawasan kajian mempunyai nilai kekerasan yang jauh lebih tinggi dengan mod nilai lantunan tukul Schmidt berjulat 56-60 berbanding dengan kekerasan batuan kuarzit di Bangi Golf Resort, Bandar Baru Bangi, Selangor (Abdul Ghani Rafek et al. 2002). Nilai pantulan tukul Schmidt yang dilaporkan bagi batuan kuarzit gred I di Bangi Golf Resort ialah 22-23 dengan indeks kekuatan beban titik di antara 1.0-2.0 $\mathrm{MPa}$. Ini mencadangkan sampel batuan kuarzit yang terdapat di kawasan persampelan mempunyai gred luluhawa I. Ujian kekerasan Skleroskop Shore bagi sampel kuarzit menunjukkan kebanyakan mineral mempunyai kekerasan Shore berjulat sekitar 61100. Mod kekerasan yang diperoleh ialah 81-90. Cuma sedikit mineral yang mempunyai nilai kekerasan Shore yang terlampau rendah menggambarkan hanya sedikit mineral yang terluluhawa. Halaju sonik mampatan $\left(\mathrm{V}_{\mathrm{p}}\right)$ sampel teras kuarzit adalah berjulat $4417-5238 \mathrm{~m} / \mathrm{s}$. Nilai purata halaju sonik mampatan $\left(\mathrm{V}_{\mathrm{p}}\right)$ yang diperoleh ialah $4985 \mathrm{~m} / \mathrm{s}$. Ringkasan hasil ujian geomekanik ditunjukkan dalam Jadual 2.

Daripada ujian kemiringan, nilai PKK batu kuarzit adalah sekitar 8 hingga 12 manakala batu filit lebih rendah iaitu 4 hingga 6 . Sudut geseran puncak $\left(f_{p}\right)$ bagi sampel batuan kuarzit dengan Pekali Kekasaran Kekar, PKK 8-10 ialah $61^{\circ}$ manakala sudut geseran puncak $\left(f_{p}\right)$ untuk PKK 10-12 ialah $73^{\circ}$. Sudut geseran puncak $\left(f_{p}\right)$ sampel batuan filit yang mempunyai PKK 4-6 ialah $56^{\circ}$. Hasil ujian kemiringan ditunjukkan dalam Jadual 3.

JADUAL 2. Sifat geomekanik batuan kuarzit dan filit, Laman Granview, Saujana Puchong, Selangor Darul Ehsan

\begin{tabular}{llccc}
\hline Litologi & Jenis ujian & Bilangan & Nilai & Purata \\
\hline Kuarzit & Kekuatan mampatan sepaksi & 6 & $75-207 \mathrm{MPa}$ & $131.1 \mathrm{MPa}$ \\
& Indeks kekuatan beban titik (sampel teras) & 6 & $1.77-10.06 \mathrm{MPa}$ & $8.14 \mathrm{MPa}$ \\
& Indeks kekuatan beban titik (sampel ketulan) & 5 & $0.63-3.44 \mathrm{MPa}$ & $1.89 \mathrm{MPa}$ \\
& Kekuatan regangan (Brazil) & 5 & $6.27-19.34 \mathrm{MPa}$ & $7.51 \mathrm{MPa}$ \\
& Pantulan tukul Schmidt & 240 & $56-60$ & 58 \\
& Kekerasan Skleroskop Shore & 120 & $61-100$ & $81-90$ \\
& Halaju sonik mampatan (V) & 12 & $4417-5238 \mathrm{~m} / \mathrm{s}$ & $4985 \mathrm{~m} / \mathrm{s}$ \\
Filit & Kekuatan mampatan sepaksi & 5 & $5.76 \mathrm{MPa}$ & - \\
& Indeks kekuatan beban titik (sampel ketulan) & 5 & $0.09-0.6 \mathrm{MPa}$ & $0.25 \mathrm{MPa}$ \\
\hline
\end{tabular}

JADUAL 3. Pekali kekasaran kekar (JRC) dan sudut geseran bagi sampel batuan kuartzit dan filit, Laman Granview, Saujana Puchong, Selangor Darul Ehsan

\begin{tabular}{ccccc}
\hline $\begin{array}{c}\text { No } \\
\text { Sampel }\end{array}$ & $\begin{array}{c}\text { Pekali Kekasaran } \\
\text { Kekar }(J R C)\end{array}$ & Litologi & $\begin{array}{c}\text { Sudut Geseran } \\
\text { Puncak }\left(\phi_{\mathrm{p}}\right)\end{array}$ & $\begin{array}{c}\text { Purata Sudut Geseran } \\
\text { Puncak }\left(\phi_{\mathrm{p}}\right)\end{array}$ \\
\hline K1 & $8-10$ & Kuarzit & 55 & 61 \\
K2 & $8-10$ & Kuarzit & 66 & 73 \\
K3 & $10-12$ & Kuarzit & 75 & \\
K4 & $10-12$ & Kuarzit & 71 & \\
F1 & $4-6$ & Filit & 67 & 56 \\
F2 & $4-6$ & Filit & 58 & \\
F3 & $4-6$ & Filit & 33 & \\
F4 & $4-6$ & Filit & 57 & \\
F5 & $4-6$ & Filit & 65 & \\
\hline
\end{tabular}


Hasil survei ketakselanjaran menunjukkan terdapat empat (4) set ketakselanjaran yang utama di cerun L1 dengan nilai arah kemiringan/sudut kemiringan $62^{\circ} / 42^{\circ}$, $261^{\circ} / 79^{\circ}, 281^{\circ} / 59^{\circ}$ dan $237^{\circ} / 71^{\circ}$. Di cerun L2, terdapat tiga (3) set ketakselanjaran utama iaitu dengan nilai arah kemiringan/sudut kemiringan $81^{\circ} / 41^{\circ}, 171^{\circ} / 71^{\circ}$ dan $198^{\circ} / 60^{\circ}$. Arah kemiringan/sudut kemiringan muka cerun L1 dan L2 ialah $62^{\circ} / 42^{\circ}$ dan $80^{\circ} / 64^{\circ}$. Analisis kinematik cerun L1 menunjukkan keadaan cerun adalah stabil. Analisis kinematik cerun L2 pula menunjukkan terdapat potensi kegagalan seperti yang ditunjukkan dalam Rajah 4 dan 5. Terdapat tiga (3) set ketakselanjaran di cerun L2, set $\mathrm{J} 1\left(81^{\circ} / 41^{\circ}\right)$ mempunyai orientasi arah kemiringan yang selari dengan muka cerun $\left(80^{\circ} / 64^{\circ}\right)$ dan menyebabkan ada keupayaan kegagalan satah berlaku. Namun, sudut geseran puncak $\left(f_{p}\right)$ yang tinggi iaitu $60^{\circ}$ menghalang kegagalan berlaku. Dengan peningkatan darjah luluhawa dan penyusutan sudut geseran permukaan dengan masa, keberangkalian kegagalan akan bertambah.

Hasil pengelasan jasad batuan dengan menggunakan sistem perkadaran jasad batuan $\left(\mathrm{RMR}_{\mathrm{asas}}\right)$ menunjukkan jasad batuan cerun L1 dan L2 yang mempunyai litologi kuarzit dan filit adalah tergolong dalam kelas II yang merupakan jasad batuan yang baik seperti yang ditunjukkan dalam Jadual 4 dan 5. Mengikut cadangan Bieniawski (1979), sudut geseran jasad dan kejelekitan jasad batuan untuk kedua dua cerun L1 dan L2 yang mempunyai litologi kuarzit dan filit adalah $35^{\circ}-45^{\circ}$ dan $300-400 \mathrm{kN} / \mathrm{m}^{2}$.

\section{KESIMPULAN}

Hasil ujian geomekanik batuan menunjukkan jasad batuan di kawasan kajian adalah kuat. Analisis kestabilan cerun menunjukkan cerun potongan L1 adalah stabil

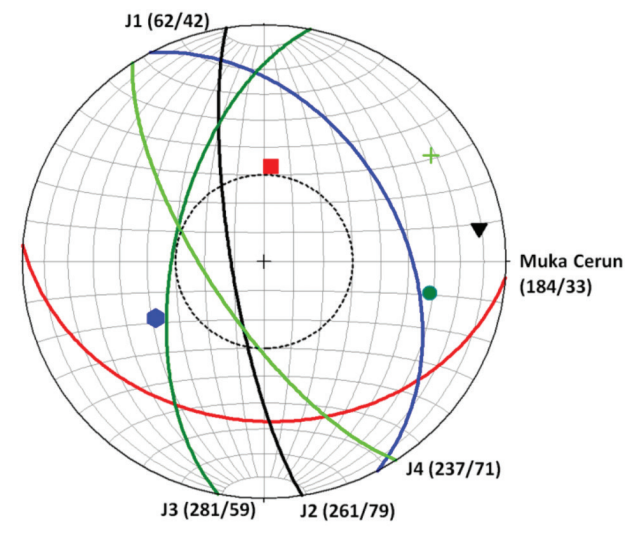

RAJAH 4. Analisis kinematik untuk cerun L1 Laman Granview, Saujana Puchong, Selangor Darul Ehsan. Arah kemiringan dan sudut kemiringan J1, J2, J3, J4 dan muka cerun adalah $62^{\circ} / 42^{\circ}, 261^{\circ} / 79^{\circ}, 281^{\circ} / 59^{\circ}, 237^{\circ} / 71^{\circ}$ dan $184^{\circ} / 33^{\circ}$. Sudut geseran puncak (f $f_{p}$ ) yang digunakan adalah $60^{\circ}$. Cerun ini adalah stabil

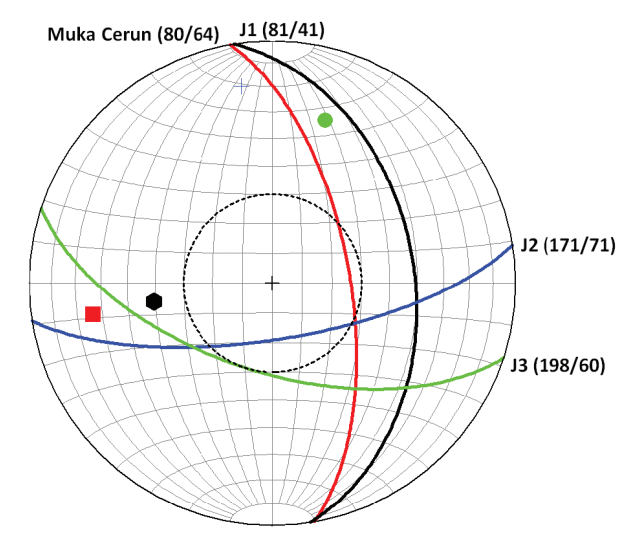

RAJAH 5. Analisis kinematik untuk cerun L2, Laman Granview, Saujana Puchong, Selangor Darul Ehsan. Arah kemiringan dan sudut kemiringan J1, J2, J3 dan muka cerun adalah $81^{\circ} / 41^{\circ}$, $171^{\circ} / 71^{\circ}, 198^{\circ} / 60^{\circ}$ dan $80^{\circ} / 64^{\circ}$. Sudut geseran puncak (f ) yang digunakan adalah $60^{\circ}$. Set J1 mempunyai orientasi jurus yang selari dengan muka cerun dan menyebabkan ada keupayaan kegagalan satah berlaku. Namun, sudut geseran yang tinggi iaitu $60^{\circ}$ menghalang kegagalan berlaku. Cerun ini adalah stabil 
JADUAL 4. Pengelasan jasad batuan berdasarkan perkadaran jasad batuan asas $\left(\mathrm{RMR}_{\text {asas }}\right)$ bagi batuan kuarzit, Laman Granview, Saujana Puchong, Selangor Darul Ehsan

\begin{tabular}{|c|c|c|c|}
\hline No & Parameter & Julat nilai/ Penerangan & Nilai perkadaran \\
\hline \multirow[t]{3}{*}{1} & Kekuatan utuh bahan batuan & & \\
\hline & Indeks kekuatan beban titik (MPa) & 8 & 12 \\
\hline & Kekuatan mampatan sepaksi ( $\mathrm{MPa})$ & 131 & \\
\hline 2 & Penanda mutu batuan, RQD (\%) & 86 & 17 \\
\hline 3 & Jarak antara ketakselanjaran (mm) & $60-200$ & 8 \\
\hline 4 & Keadaan ketakselanjaran & $\begin{array}{l}\text { Permukaan sedikit kasar } \\
\text { Bukaan }<1 \mathrm{~mm} \\
\text { Satah sedikit terluluhawa }\end{array}$ & 25 \\
\hline 5 & Kehadiran air & Kering & 15 \\
\hline 6 & Jumlah nilai perkadaran $\left(\mathrm{RMR}_{\text {asas }}\right)$ & \multicolumn{2}{|c|}{77} \\
\hline 7 & Kelas & \multicolumn{2}{|c|}{ II (RMR 61-80) } \\
\hline 8 & Sudut geseran jasad batuan $\left(^{\circ}\right)$ & \multicolumn{2}{|c|}{$35-45$} \\
\hline 9 & Jelekitan jasad batuan $\left(\mathrm{kN} / \mathrm{m}^{2}\right)$ & \multicolumn{2}{|c|}{$300-400$} \\
\hline 10 & Pengelasan jasad batuan & \multicolumn{2}{|c|}{ Batuan yang baik } \\
\hline
\end{tabular}

JADUAL 5. Pengelasan jasad batuan berdasarkan perkadaran jasad batuan asas $\left(\mathrm{RMR}_{\text {asas }}\right)$ bagi batuan filit, Laman Granview, Saujana Puchong, Selangor Darul Ehsan

\begin{tabular}{|c|c|c|c|}
\hline No. & Parameter & Julat nilai/ Penerangan & Nilai perkadaran \\
\hline \multirow[t]{2}{*}{1} & Kekuatan utuh bahan batuan & & \\
\hline & $\begin{array}{l}\text { Indeks Kekuatan beban titik }(\mathrm{MPa}) \\
\text { Kekuatan mampatan sepaksi }(\mathrm{MPa})\end{array}$ & $\begin{array}{c}0.25 \\
5.8\end{array}$ & 1 \\
\hline 2 & Penanda mutu batuan, RQD (\%) & 86 & 17 \\
\hline 3 & Jarak antara ketakselanjaran (mm) & $60-200$ & 8 \\
\hline 4 & Keadaan ketakselanjaran & $\begin{array}{l}\text { Permukaan sedikit kasar } \\
\text { Bukaan }<1 \mathrm{~mm} \\
\text { Satah sedikit terluluhawa }\end{array}$ & 25 \\
\hline 5 & Kehadiran air & Kering & 15 \\
\hline 6 & Jumlah nilai perkadaran $\left(\mathrm{RMR}_{\text {asas }}\right)$ & \multicolumn{2}{|l|}{66} \\
\hline 7 & Kelas & \multicolumn{2}{|c|}{ II (RMR 61-80) } \\
\hline 8 & Sudut geseran jasad batuan $\left({ }^{\circ}\right)$ & \multicolumn{2}{|c|}{$35-45$} \\
\hline 9 & Jelekitan jasad batuan $\left(\mathrm{kN} / \mathrm{m}^{2}\right)$ & \multicolumn{2}{|c|}{$300-400$} \\
\hline 10 & Pengelasan jasad batuan & \multicolumn{2}{|c|}{ Batuan yang baik } \\
\hline
\end{tabular}

kerana orientasi set-set ketakselanjaran tidak memotong permukaan cerun. Cerun potongan L2 pula mempunyai keupayaan kegagalan satah tetapi kekasaran satah menghalang gelongsoran berlaku. Daripada pengelasan jasad batuan dengan menggunakan sistem perkadaran jasad batuan, RMR (Bieniawski 1979), didapati nilai perkadaran yang diperoleh bagi kedua-dua jenis batuan untuk cerun L1 dan L2 tergolong dalam Kelas II iaitu batu kuarzit 77 manakala batu filit ialah 66. Oleh itu, boleh disimpulkan bahawa jasad batuan di kawasan kajian ialah Kelas II yang merupakan jasad batuan yang baik.

\section{PENGHARGAAN}

Penulis mengucap ribuan terima kasih kepada program Geologi, khususnya pembantu makmal, En. Jailani Miskam dan En. Mohd Sis Maswan atas bantuan dan kerjasama serta kemudahan dan kelengkapan yang disediakan pada peringkat program. Kajian ini dijalankan menggunakan peruntukan geran dalaman Universiti Kebangsaan Malaysia, GUP-2018-116 dan program sabatikal Universiti Kebangsaan Malaysia.

\section{RUJUKAN}

Abdul Ghani, R. \& Goh, T.L. 2015. A systematic approach for the quantification of rock slope stability. Dalam Engineering Geology for Society and Territory Volume 2, disunting oleh Lollino, G., Giordan, D., Crosta, G.B., Corominas, J., Azzam, R., Wasowski, J. \& Scirra, N. London: Springer.

Abdul Ghani, R. \& Goh, T.L. 2012. Correlation of joint roughness coefficient (JRC) and peak friction angles of discontinuities of Malaysian Schists. Earth Science Research 1(1): 57-63.

Abdul Ghani Rafek, Siti Rashidah Mohd Rasid \& Abdul Rahim Shamsudin. 2002. Sifat geologi kejuruteraan batuan kuarzit 
di Bangi Golf Resolf, Bandar Baru Bangi, Selangor Darul Ehsan. Bulletin Geological Society of Malaysia 45: 19-22.

Abdullah Sani, H.H. 1985. Discovery of an ammonoid (Agathiceras sp.) and crinoids stems in the Kenny Hill Formation of Peninsular Malaysia, and its significance. Warta Geologi 11(5): 205-209.

Ailie, S.S., Goh, T.L., Abdul Ghani, R., Azimah, H., Lee, K.E. \& Tuan Rusli, M. 2017. Peak friction angle estimation from joint roughness coefficient of discontinuities of limestone in Peninsular Malaysia. Sains Malaysiana 46(2): 181-188.

Ailie, S.S., Goh, T.L., Abdul Ghani, R., Norbert, S., Azimah, H., Lee, K.E., Noraini, S. \& Tuan Rusli, M. 2016. Development of empirical correlation of peak friction angle with surface roughness of discontinuities using tilt test. AIP Conf. Proceedings 060033(2016): https://doi. org/10.1063/1.4966871.

Bieniawski, Z.T. 1979. The geomechanics classification in rock engineering application. Proceedings of the 4th International Congress on Rock Mechanics 2: 41-48.

Brown, E.T. (pnyt). 1981. Rock Characterization Testing and Monitoring: ISRM Suggested Methods. Great Britain: Pergamon Press.

Deere, D.U. 1963. Technical description of rock cores for engineering purpose. Rock Mech. Eng. Geol 1: 18-22.

Goh, T.L., Abdul Ghani, R., Ailie, S.S., Azimah, H. \& Lee, K.E. 2016a. Use of ultrasonic velocity travel time to estimate uniaxial compressive strength of granite and schist in Malaysia. Sains Malaysiana 45(2): 185-193.

Goh, T.L., Selim Reza, M., Abdul Ghani, R., Ailie, S.S., Azimah, H. \& Lee, K.E. 2016b. Assessment of ultimate bearing capacity based on the Hoek-Brown failure criterion. Sains Malaysiana 45(11): 1603-1607.

Goh, T.L., Ainul, M.M.R., Nur Amanina, M., Abdul Ghani, R., Nur Ailie, S.S. \& Tuan Rusli, M. 2016c. Rock slope stability assessment using slope mass rating (SMR) method: Gunung Lang Ipoh Malaysia. Scholar Journal of Engineering and Technology 4(4): 185-192.

Goh, T.L., Abdul Ghani, R., Ailie, S.S., Norbert, S., Lee, K.E. \& Azimah, H. 2015a. Empirical correlation of uniaxial compressive strength and primary wave velocity of Malaysian Schists. Electronic Journal Geotechnical Engineering 20: 1801-1812.

Goh, T.L., Abdul Ghani, R., Ailie, S.S., Norbert, S., Azimah, H. \& Lee, K.E. 2015b. Correlation of ultrasonic velocity slowness with uniaxial compressive strength of schists in Malaysian. Electronic Journal Geotechnical Engineering 20: 12663-12670.

Goh, T.L., Ghani Rafek, A. \& Hariri Arifin, M. 2014a. Correlation of joint roughness coefficient with peak friction angles of discontinuity planes of granite, Peninsular Malaysia. Sains Malaysiana 43(5): 751-756.
Goh, T.L., Abdul Ghani, R., Ailie, S.S., Norbert, S. \& Lee, K.E. 2014b. Empirical correlation of uniaxial compressive strength and primary wave velocity of Malaysian granites. Electronic Journal Geotechnical Engineering 19(E): 1063-1072.

Goh, T.L., Abdul Ghani, R. \& Hariri, A. 2012. Geomechanical strength of granites and schists of Peninsular Malaysia. Sains Malaysiana 41(2): 193-198.

Google Map. 2017. Laman Granview. https://www.google.com/ maps/place/Laman+Granview,+47100+Puchong,+Selangor, +Malaysia. Diakses pada 27 Mac 2017.

Hoek, E. \& Bray, J. 1981. Rock Slope Engineering. Edisi Ke-3. London: The Institution of Miningand Metallurgy.

Ibrahim Komoo \& Ibrahim Abdullah. 1983. Ketakselanjaran dan kaedah pengukuran di lapangan. Sains Malaysiana 12(2): 119-140.

Ibrahim Komoo, Ibrahim, Abdullah \& Juhari Mat Akhir. 1985. Ketakselanjaran dan kestabilan cerun batuan di Bukit Taman Melawati, Wilayah Persekutuan. Sains Malaysiana 14(1): 65-82.

Norbert, S., Rodeano, R., Abdul Ghani, R., Goh, T.L., Noran, N.N.A., Kamilia, S., Nightingle, L.M., Azimah, H. \& Lee, K.E. 2016. Rock mass assessment using geological strength index (GSI) along the Ranau-Tambunan Road, Sabah, Malaysia. Research Journal of Applied Sciences, Engineering and Technology 12(1): 108-115.

Stauffer, P.H. 1973. Kenny Hill formation. Dlm Geology of the Malay Peninsula, disunting oleh Gobbet, D.J. \& Hutchinson, C.S. New York: John Wiley \& Son. Inc.

Ong Bok Cheng \& Goh Thian Lai*

Program Geologi

Pusat Pengajian Sains Sekitaran dan Sumber Alam

Fakulti Sains dan Teknologi

Universiti Kebangsaan Malaysia

43600 UKM Bangi, Selangor Darul Ehsan

Malaysia

Abdul Ghani Rafek

Department of Geosciences

Universiti Teknologi PETRONAS

Bandar Seri Iskandar

31750 Tronoh, Perak Darul Ridzuan

Malaysia

*Pengarang untuk surat menyurat; email: gdsbgoh@gmail.com

Diserahkan: 28 Mac 2017

Diterima: 28 September 2017 